\title{
Cartografías del barroco \\ en América Latina
}

\section{Baroque mapping in Latin America}

DOI: $10.12957 /$ ek.2016.25048

Dra. María José Rossi

majorossi@hotmail.com

Universidad de Buenos Aires - Argentina

Una cartografía reúne, por lo general, el conjunto de los mapas que representan territorios y espacios; incluye también mapas topográficos que muestran texturas y relieves. De eso trata el barroco: de cuerpos en el espacio, textos, texturas, densidades. Este artículo intenta, pues, de ofrecer una cartografía del barroco en América Latina. La primera parte contiene una breve presentación de las discusiones acerca del barroco que a partir del siglo XIX tienen lugar en el ámbito europeo; luego se realiza un recorrido por ensayistas y poetas latinoamericanos que han reflexionado sobre el barroco como una manera de responder a la pregunta acerca de la identidad de América.

PALABRAS-CLAVE Barroco. Hermenéutica. América Latina. Identidad

Mapping usually collects the set of maps representing areas and spaces; it also includes topographic maps showing textures and reliefs. That is what the Baroque presents: bodies in space, texts, textures, densities. This article aims to provide a mapping of the Baroque in Latin America. The first part contains a brief presentation of the discussions about the Baroque in Europe from the nineteenth century; then it offers a route by essayists and Latin American poets who have reflected on the Baroque as a way to answer the question about the identity of America.

KEY-WORDS Baroque. Hermeneutic. Latin America. Identity 
Las primeras discusiones en torno del barroco tienen lugar apenas iniciado el siglo XIX, casi 200 años después de que los historiadores del arte reconocieran su primer despertar como estilo artístico y literario en el s. XVII. El término "barroco" — de cuya incierta etimología se ha ocupado B. Croce (1929), entre otros - se aplica, pues, retroactivamente, conforme a los parámetros jerarquizantes de lo "clásico". Su reconocimiento como forma artística, e incluso, como ethos cultural y forma de vida — de ahí la expresión "Señor Barroco", que acuñara el escritor cubano José Lezama Lima - es por tanto contemporáneo a su implantación en la América lusitana y española. Sin embargo, a diferencia de su par metropolitano, el barroco adoptará en estas tierras características propias: los procesos de mestizaje e hibridización implicados en él conllevan reapropiaciones y nuevas formas de lectura (Zea, 1987).

Lo que nos proponemos en lo que sigue es compendiar, en modo sumario, a los principales teóricos del barroco en el ámbito continental europeo (PARTE I) para dar cuenta luego de su implante, apropiación y reinterpretación en territorio latinoamericano (PARTE II). En relación con la parte I, nos interesa ofrecer una orientación más bien esquemática, un mínimo estado de la cuestión, acerca de diferentes perspectivas que animaron el debate sobre la valoración del barroco desde fines del siglo XIX, muchas de las cuales han incidido en el modo en que el barroco es reelaborado por novelistas, ensayistas y poetas locales.

En relación a la segunda parte, dada la profusión y heterogeneidad del material sobre el tema, hemos ordenado el material de acuerdo con los siguientes criterios: a) textos fundantes que inauguran las reflexiones sobre el barroco latinoamericano estableciendo en mayor o en menor medida su estatuto y su especificidad; b) textos críticos y ensayísticos que proponen una tesis o una perspectiva singular. El trabajo apunta asimismo a ponderar la significación del siglo XVII y del "barroco de Indias" a los fines de aportar a una problemática que ha ocupado a sucesivas generaciones desde los años '40: la cuestión de la identidad-diferencia americana ligada al modo del "ser nacional". Es en el contexto preciso de estas discusiones, que los conceptos de barroco y de neobarroco adquieren la significación que le es propia; significación que, unida a una conciencia que es a la vez europea, mestiza y criolla, coincide con el despertar, a decir de Martí, de "Nuestra América". 


\section{El barroco: la mirada europea}

Antecedentes. En La estética del Barroco (2014), Jon Snyder encuentra en el conceptismo "la expresión más radical y original del fenómeno barroco". Entre sus precursores, Snyder destaca a los pensadores y poetas conceptistas italianos Francesco Patrizi (1529), Jacopo Mazzoni (1548-1598), Torcuato Tasso (1544-1595) y Camillo Pellegrino (1527-1603). Entre los escritores de habla hispana, será Baltazar Gracián quien hará del "arte del ingenio" un precedente del barroco, arte que estimula el pensamiento y la invención de conceptos a través del empleo figuras retóricas y poéticas. En abierta ruptura con Aristóteles y con toda la tradición clásica, los conceptos no son, para Gracián, puras abstracciones, ni el arte mímesis, sino el resultado del descubrimiento de relaciones, afinidades y correspondencias entre elementos no evidentes al sentido común. Producto de la agudeza, el texto es un conjunto de nexos, interconexiones y relaciones que escapan al pensamiento racional, mientras que el propio mundo resulta ser jeroglífico y emblema. Se ponen así las bases de la inversión mundo-mapa / original-copia que tendrá plena expresión en el barroco del s. XVII y que al que retornarán las poéticas del s. XX (Borges).

Lecturas y perspectivas. La puesta en cuestión de la jerarquía implícita en el par original-copia y mundo-texto, anticipada por el conceptismo, cobrará vigor en el s. XVII. Las artes plásticas y la arquitectura de los países de la contrarreforma (fundamentalmente Italia y España, pero también Austria, Alemania y Checoslovaquia), registran en ese siglo una clara tendencia a la exacerbación de los contrastes, a las concavidades, la curvatura y la ornamentación (Bernini, Adam, Churriguera); el tenebrismo en pintura (Caravaggio) coincide con elucubraciones lúgubres sobre el sentido de la existencia (Corneille, Racine, Dryden, Gryphius). La concepción de la vida como teatro y del mundo como escenario (Calderón de la Barca) se asocia a una melancolía creciente, como observará Walter Benjamin (1928, 2012). Hay coincidencia en que se trata de un periodo de crisis e inestabilidad (Hauser, 1978), expresado en diferentes órdenes, desde filosóficos (Descartes) hasta artísticos. Por eso hay quienes verán en el barroco no sólo un estilo sino una mentalidad, una actitud ante la vida, una ideología (Skrine, 1987, García de la Concha, 1990).

Es claro también que en la asignación retroactiva del término hay una valoración peyorativa implícita, pues en su misma errancia etimológica el barroco evoca todos aquellos fenómenos del arte que, vistos desde una perspectiva y una sensibilidad clasicistas, resultan desmesurados, confusos, extravagantes. Basado en los principios clásicos del Renacimiento, Cornelius Gurlitt (Ges- 
chichte des Barockstils in Italien, 1887) lo define como un estilo propenso a la exageración expresiva y a la pomposidad. La gravitación de esta perspectiva se extenderá por mucho tiempo más. Para B. Croce (Storia dell 'età barocca in Italia, 1929), el barroco derrocha "mal gusto", al punto de considerar que "lo que es verdaderamente arte no es barroco, lo que es barroco, no es arte". En Die Cultur der Renaissance in Italien (La cultura del Renacimiento en Italia, 1860) J. Burckhardt denomina al barroco como un "dialecto corrupto" del Renacimiento (o "dialecto salvaje": "Die Barockbaukunst spricht dieselbe Sprache, wie die Renaissance, aber einen verwilderten Dialekt davon"), sin atribuirle, sin embargo, una connotación del todo despectiva.

La reivindicación vendrá por vía del formalismo. Serán Heinrich Wölfflin (Renaissance und Barock, 1888 [Renacimiento y Barroco]; Kunstgeschichtliche Grundbegriffe, 1915 [Conceptos fundamentales de la Historia del Arte]) y Allois Riegl (Die Entstehung der Barockkunst in Rom, 1908), los que cambien enteramente el punto de vista y, con ello, la valoración interpretante. La perspectiva es del todo innovadora y tendrá una influencia perdurable, ante todo, porque permitirá dejar de ver el barroco como un apéndice del Renacimiento. Wölfflin define los estilos renacentista y barroco como dos modos opuestos de representación según los conceptos duales de lineal/pictórico, superficial/profundo, múltiple/unitario, claridad absoluta/claridad relativa. De este modo, los convierte en categorías ideales constante en la historia, que se van alternando conforme a variaciones de gusto. Discípulo de Riegl, Wilhelm Worringer - cuya teoría de la "voluntad de forma" incidirá notablemente en los escritores de habla hispana en los años 30, en particular en Lezama Lima — va en la misma dirección: barroca es toda forma estilística que muestra una vida orgánica bajo "una presión demasiado fuerte". El "patetismo transcendental" del barroco se distingue así de la armonía y equilibrio propios el estilo clásico. La secuencia: trascendentalismo gótico - intermezzo del Renacimiento - trascendentalismo barroco se continúa en los románticos y expresionistas de posguerra, a través de los cuales el barroco adopta nuevas configuraciones (Formprobleme der Gotik, 1911).

Poco tiempo después del texto de Wölfflin, Der Barock als Kunst der Gegenreformation, de 1921 [El barroco, arte de la Contrarreforma, 1948] de Werner Weisbach, abre una nueva perspectiva, ubicando el barroco en el contexto específico de la contrarreforma católica y de las monarquías absolutas.

1 "De las modalidades que pudiéramos señalar en un barroco europeo, acumulación sin tensión y asimetría sin plutonismo, derivadas de una manera de acercarse al barroco sin olvidar al gótico y de aquella definición tajante de Worringer: el barroco es un gótico degenerado" (Lezama Lima, 2014, p. 228). 
Inaugura así el enfoque historicista, que confiere al barroco características que sólo se comprenden en el marco del siglo XVII. En lo sucesivo, críticos e historiadores se identificarán, ya sea con perspectiva formal, ya sea con la histórica, o bien tenderán a cruzarlas, como es el caso de Arnold Hauser (The social History of Art, 1951 [Historia social de la Literatura y el Arte, 1978]). Para Hauser, en efecto, no se puede hablar de un estilo de época unitario, "pues en cada momento hay tantos estilos diversos cuantos son los grupos sociales que producen arte" (1978, p. 99): así como el barroco cortesano y católico es sensual, monumental y decorativo, el barroco burgués y protestante resulta riguroso y estricto. Hauser ubica la emergencia del barroco en la crisis del s. XVII, con la consolidación del capitalismo y la sociedad burguesa, pero a la vez encuentra que la recurrencia de las crisis generan un fenómeno concomitante que se repite y vuelve cada vez.

De este modo, vemos que el fenómeno puede leerse desde tres grandes perspectivas, ya sea que se lo reconozca, a grandes rasgos, en su dimensión formal (a), en su vertiente histórica (b), o en la modalidad que Iriarte (2011) llama recursiva (c), la cual intenta resolver la contradicción, señalada por Calabrese (1987), entre el concepto abstracto de "estilo" o "forma artística" y el plano histórico.

(a) El barroco en su dimensión formal reaparece con Henry Focillon ( $L a$ vie des formes, 1934) y con Eugenio d'Ors (Lo barroco, 1936), quien lo concibe en clave metafísica transhistórica, como una categoría del espíritu formado por constantes denominadas 'eones'. Focillon, por su parte, considera que dentro de cada estilo artístico existe una lógica interna de evolución caracterizada por distintas fases: arcaica o preclásica, clásica, manierista (de refinamiento) y barroca. Dichos estadios evolutivos implican transformaciones morfológicas equivalentes al de un sistema biológico (generación-perfeccionamiento-degeneración). En tiempos recientes, Omar Calabrese ( L'età neobarroca, 1987 [ La era neobarroca, 1987]) retoma el enfoque formal para considerar el barroco como una "categoría de la forma" que pone en consonancia diferentes planos de la cultura, siendo característico de estos tiempos el neobarroco. Se trata de reconocer en los fenómenos culturales, considerados textos, las "morfologías subyacentes" que determinan un "gusto" o un "estilo". Finalmente, Gilles Deleuze (Le pli. Leibniz et le baroque, 1988, 2005) convierte el pliegue barroco en categoría formal operatoria (o concepto práctico), el cual permite leer/interpretar una realidad histórica en su singularidad: el plegado como mecanismo de constitución universal y como método de comprensión va de la mónada leibniziana a las cadenas de ADN y a la arquitectura. 
(b) Giulio Carlo Argan (L'architettura barocca in Italia, 1957; Immagine e persuasione, 1986 [Renacimiento y Barroco tomos I y II, 1987]) señala la importancia de la retórica y la sugestión del barroco, a la vez que subraya las diferencias entre el carácter cortesano del barroco italiano y la religiosidad del español. Gillo Dorfles (Architetture ambigue: Dal Neobarocco al Postmoderno, en particular su ensayo "Barocco nell'architettura moderna", 1951) añade al marco histórico de emergencia los aspectos socio-antropológicos del barroco, a los que cruza con instrumentos de la lingüística. Con un campo cronológico limitado a la primera mitad del siglo XVII, especialmente al reinado de Felipe IV, el español José Antonio Maravall (La cultura del barroco, 2012) desvela los procedimientos de maquinación del teatro y de la fiesta barrocas como formas de propaganda de la monarquía austríaca. La cultura del barroco es así programada e intervenida desde el poder, desde la alianza trabada por la monarquía, la aristocracia tradicional y el jesuitismo contrarreformista para preservar los privilegios de los poderosos y las diferencias estamentales en la conflictiva sociedad del s. XVII español. Siguiendo esta línea, para José Luis Marzo ( $L a$ memoria administrada, 2000), el barroco fue un aparato de dominio colonial, un injerto que los españoles trajeron a América, destinado a administrar la memoria de los vencidos. Considerado un puro proceso de hispanización, muy lejano de todo ethos cultural originario, el barroco consistió en la adaptación de las tradiciones icónicas locales a la nueva formalidad católica; en otras palabras, se trató de un sincretismo formal. El barroco sería una empresa llevada a cabo para borrar y aniquilar la cultura de origen.

(c) Finalmente, entre los que adoptan un enfoque recursivo, el italiano Luciano Anceschi (L'idea del barocco, 1984) propone considerar al barroco como un sistema integrado por invariantes formales que sólo se comprenden a partir de su descripción histórica determinada. Y a la inversa: sólo a partir de principios formales, un evento históricamente definido puede delimitarse con exactitud.

\section{EI barroco: la mirada latinoamericana}

Como resultado de su implante en un espacio completamente heterogéneo al de su ámbito de emergencia, el barroco en América Latina (en adelante AL) desarrolla características propias, tanto en la literatura como en los demás artes. La revalorización del barroco coincide aquí con la recuperación del barroco áureo que la generación del 27 lleva a cabo en España a partir de la relectura de Góngora. Resulta decisivo, a tal efecto, el encuentro de Lezama Lima con Juan 
Ramón Jiménez en Cuba, así como los contactos de españoles con el grupo nucleado en torno de la revista Orígenes, entre los que se encuentra Alfonso Reyes (Wasem, 2008).

Reseñaremos brevemente en lo que sigue el trabajo de los pioneros, entre los cuales el venezolano Mariano Federico Picón Salas (Mérida, 1901- Caracas, 1965) ocupa un lugar destacado: a él debemos la expresión "barroco de Indias" y el intento por proponer un abordaje histórico del mismo. Su ensayo De la conquista a la independencia, a principios de los años 40, se da en momentos en que comienza a darse el debate por una definición de lo americano en sus propios términos. Siguen luego los escritos de aquellos que, siendo a la vez poetas, dramaturgos o novelistas, han contribuido, con reflexiones y análisis más o menos dispares sobre el tema, a trazar parte de su derrotero (sin que, por otro lado, pueda hablarse de un "programa barroco" como tal), de los cuales sólo tomaremos en cuenta su producción teórico-ensayística: José Lezama Lima ( $\mathrm{La}$ Habana, Cuba, 1910-1976), Haroldo de Campos (São Paulo, Brasil, 1929-2003) y Alejo Carpentier (La Habana, 1904 - París, 1980) entre los años 50 y 60 . A esos trabajos primerizos seguirán, en los 70, los de Octavio Paz (México DF, 1914-1998) y los de Severo Sarduy (Camagüey, Cuba 1937-1993), cuyo texto fundamental, "Barroco y neobarroco", inaugura el denominado "neobarroco". En tiempos recientes, Néstor Perlhonger (Avellaneda, Argentina, 1949 - San Pablo, Brasil, 1992) y Roberto Echavarren (Montevideo, 1944), han vuelto sobre la cuestión: el neobarroco es, para estos autores, tanto una experimentación inherente a la práctica poética y política como una dimensión meta-reflexiva en el que ambos momentos se solapan: la reflexión se torna inmanente a los textos poéticos, la poesía se insinúa en los ensayos.

\section{Textos fundadores}

\section{Mariano Picón Salas: el barroco de Indias}

En De la conquista a la independencia. Tres siglos de historia cultural hispanoamericana (1944), Picón Salas señala: "La época colonial, y especialmente el periodo barroco (...) es el más desconocido e incomprendido en todo nuestro proceso cultural-histórico". Para el historiador y ensayista venezolano, el desconocimiento del barroco en América corre parejo con su insondable pervivencia, pues a pesar de la influencia de la Ilustración y de la crítica moderna, "los hispanoamericanos no nos evadimos enteramente aún del laberinto barroco" (p. 123). 
El autor venezolano no sólo destaca la plena vigencia, en los años 40 , de un estilo en cuyo "laberinto" aún estamos atrapados, sino que señala la insuficiencia de sus abordajes teóricos, tanto de aquellos que se abocan a su descripción a partir de obras singulares (Burckhardt) como de los que se concentran en sus aspectos formales (Wölfflin). Echando mano del método histórico comparativo, Picón Salas adopta así un enfoque alejado de todo formalismo para el estudio del barroco en América, al que denomina "barroco de Indias" (cap. VI). La expresión evoca la importancia de la locación y enfatiza un malentendido (las "Indias"), el cual precipita toda suerte de implantes e imaginarios yuxtapuestos. A la distancia existente entre el vitalismo del Renacimiento (lógico, canónico, universalista) y el vitalismo del Barroco (ornamental, preciosista, alegorizante), se suma la diferencia entre el barroco español, el italiano y el austríaco; estos, a su vez, se distinguen del barroco de Indias, resultado de la metamorfosis sufrida por el barroco católico y cortesano (que combina escolástica y represión) una vez implantado en América, es decir, una vez que se injerta en la cultura local y deviene mestizo: "En Hispanoamérica el problema presenta nuevas metamorfosis, debido al aditamento de un medio más primitivo, a la influencia híbrida que en la obra cultural produce el choque de las razas y la acción violenta del trasplante" (1944, p. 122). De ahí que el barroco sea ante todo una "cultura": un modo de vida y una modalidad del saber, caracterizado por la superposición de elementos (mitología griega, Biblia, dioses mexicanos) y el desvanecimiento de las fronteras entre diferentes disciplinas artísticas. Es la cultura barroca la que posibilita la aparición de los grandes eruditos y poetas del siglo, a quienes Picón Salas destaca por ser al mismo tiempo emergentes y artífices: el historiador Carlos de Sigüenza y Góngora (México; 1645 - 1700), el matemático, doctor en derecho, astrónomo y poeta Pedro Peralta Barnuevo (Lima, 1663-1743) y el clérigo y letrado mestizo Juan de Espinosa Mendrano, llamado El Lunarejo (Cusco 1629 - 1688); todos ellos contribuyeron al inicio de un modo de vida que intenta conciliar elementos irreductibles (Quetzalcóatl con el apóstol Tomás) y que da lugar a un arte "peregrino" (en palabras del Lunarejo) o autónomo, diferente del orden natural, pero no por ello irracional sino intenso, colorido, melódico.

Pero es sobre todo con los poetas Juan del Valle y Caviedes (Porcuna, 1652 Lima, 1697), conocido como "El poeta de la Ribera"2, y con sor Juana Inés de la Cruz (San Miguel de Nepantla, 1651 - Ciudad de México, 1695), que se alcanza en Indias la convivencia entre una literatura oficial (ornamental, cortesana y formalista) y una literatura soterrada, que es satírica y popular en el caso de Cavie-

2 Véase al respecto, en este mismo dossier, el artículo de Facundo Ruiz "El individuo, la población, uno mismo. El vínculo afectivo en la poesía amorosa de Juan del Valle y Caviedes". 
des, mordaz y metafísica en el caso de Sor Juana. La línea desenfadada y vital de la picaresca española se convierte en burla corrosiva y realismo tétrico: "La idea - tan barroca - del mundo como un teatro, como una feria de farsantes, vestidos de trajes y personalidades falsas", se hace presente en la caricaturas diseñadas por el poeta limeño, mientras que ese mismo desengaño se encubre con una coraza lógica y metafísica en el caso de la monja mexicana; de este modo "[b]usca en la geometría y en la música lo que se negó a pedir a la vida. Complicándose se apacigua" (1944, p.145). La subalternidad histórica de la mujer y del mestizo, superpuesta a un aparato de dominio cuasi-medieval y católico, pueden así explicar "la guerra civil del alma", la soledad y los dilemas que aquejan, para el escritor venezolano, el alma atribulada de nuestros primeros poetas barrocos.

\section{Lezama Lima y el barroco como plutonismo}

Abocado, como es propio de los años 50-60, a la cuestión de la identidad latinoamericana, el escritor y ensayista cubano se ocupa específicamente de la cuestión barroca en "La curiosidad barroca", título de una conferencia que, junto con otras cinco que Lezama dictó en 1957 sobre la identidad cultural americana, hará su aparición en el libro La expresión americana, publicado en 1969 [Todos esos textos, y otros de su autoría, fueron compilados recientemente en un volumen intitulado Ensayos barrocos, 2014]. Lezama no se detiene en la búsqueda de una esencia o un origen para América; eludiendo la tentación sustancialista, se empeña en cambio en la construcción de una "fábula intertextual" (la expresión es de I. Chiampi) que, por no corresponder a ninguna realidad en sí, lleva el nombre de "barroco". Su caracterización del barroco como "era imaginaria" (en "La imago y las eras imaginarias", artículo de 1953) es parte de esta operación de despegue de todo referente, pues es en ese periodo que el mundo es concebido como imagen: "La imagen como un absoluto, la imagen que se sabe imagen, la imagen como última de las historias posibles" (2014, p. 53).

Lezama atribuye las formas distorsionadas del barroco americano a la confluencia dolorosa de dos culturas cuyo acoplamiento fue a la vez creativo y mortificante. La reflexión del autor se ubica en ese entresijo, pues es en la heterogeneidad (no en el particularismo etnocéntrico) donde debe buscarse, paradójicamente, la identidad de AL. Europeos y aborígenes viven la temporalidad y la espacialidad de modo contrapuesto, lo mismo que los límites entre lo animal y lo humano. La estrategia barroca está así llamada a hacer visibles 
y vivibles las contradicciones que la colonización y el espíritu del capitalismo encienden en nuestro territorio; contradicciones que se juegan entre trabajo y acumulación de capital; entre formas de vida legitimadas y otras reprimidas, desechadas o condenadas a la existencia clandestina, pero que, pese a todo, mantienen "las exigencias de su orgullo y su despilfarro". La estrategia barroca no es por ello revolucionaria, pero tampoco conservadora (como el barroco contra-reformista), sino una forma de resistencia que opera en la dimensión simbólica, un drama de características épicas que aún no ha concluido. Dos categorías estéticas diferenciales la animan: "tensión” y "plutonismo", metáfora que, al incluir a Plutón como señor de los infiernos, permite aludir a un elemento que rompe y unifica a la vez:

Nuestra apreciación del barroco estará destinado a precisar: primero, hay una tensión en el barroco; segundo, un plutonismo, fuego originario que rompe los fragmentos y los unifica; tercero, no es un estilo degenerescente, sino plenario, que en España y en la América española representa adquisiciones de lenguaje, tal vez únicas en el mundo, muebles para la vivienda, formas de vida y de curiosidad, misticismo que se ciñe a nuevos módulos para la plegaria, maneras del saboreo y del tratamiento de los manjares, que exhalan un vivir completo, refinado y misterioso, teocrático y ensimismado, errante en la forma y arraigadísimo en sus esencias (2014, pp. 228-229).

Lezama Lima se refiere al "Señor Barroco"3 como poiesis demoníaca con la clara intención de atribuirle un sentido de rebelión: el drama político subyacente no se disocia, pues, de su propuesta estética; ambas dimensiones conforman una unidad inseparable, estético-política. Lo arquitectónico, literario y ritual rebasan los límites que separan las fronteras. El gusto por lo mutante (frente a lo fijo), lo inestable (frente a lo seguro), lo multidimensional (frente a lo unidimensional), los pliegues (frente al alisamiento de la consistencia del mundo), aplicados al arte y a la dimensión práctica de la existencia, a la estética como a la política, dan cuenta de la imposibilidad de encasillamiento. Pero lo fundamental, si se quiere, lo que lo hace expresión cabal de nuestra historia, es que

$3 \mathrm{Al}$ respecto, véase el ensayo de Alejandra González "Los pliegues del Señor Barroco", en este dossier. 
el barroco esté constituido por una voluntad de forma atrapada entre tendencias contrapuestas: la de la forma vencedora (dominante pero decadente) y la vencida (derrotada pero en emergencia). Es, en la primera, la realidad de la conquista ibérica, la del colonizador en estado de orfandad, dominante pero abandonado por la madre patria. En la segunda, la realidad de indígenas, africanos y mestizos (criollos, cholos y mulatos), compelidos a la aquiescencia pero con capacidad para un "no" camuflado, para una resistencia sorda que se hace valer por un complejo trabajo de resemiotización. Lejos de repelerse, esas formas buscan una conciliación a la vez absurda e imposible. De ahí su dramaticidad originaria, su apelación a las paradojas, a los enfrentamientos y confusión de planos de representación. Destaca por ello al indio quechua Kondori, que "en la voluminosa masa pétrea de la Compañía logra insertar símbolos incaicos de sol y luna, de abstractas elaboraciones, de sirenas incaicas, de grandes ángeles cuyos rostros de indios reflejan la desolación de la explotación minera" (2014, p. 243). Representa así la rebelión incaica, que se atreve a hacer comparecer con el capitel corintio y la trifolia griega, la semiluna incaica y la hoja americana. El drama épico que se pone en juego en el barroco latinoamericano no es entonces sólo el que abraza la Contrarreforma, en un intento de provocar experiencias ambivalentes y estados de vértigo que se asocia con contrarios que se interpenetran: el mundo humano y divino, la luz y las tinieblas, la virtud y el pecado, la vida y la muerte. Tampoco se deja atrapar en sus aspectos puramente estéticos y formales, como el rebasamiento de la figura por el color, la profundidad que excede la superficie, la inquietud de lo no representado avasallando lo presente, el todo sobre las partes, lo indistinto por sobre lo diferenciado, como supo mostrarlo Wölfflin (2007). Drama humano, corporal y espiritual, es un intento de reinvención de Europa y de lo prehispánico según un principio de ordenamiento que no obstante no remite a ninguna identidad sustancial ni permite estabilizar ninguna forma de vida. De ahí que Lezama Lima insista en adscribir la realidad latinoamericana a la categoría de devenir. Si el barroco latinoamericano comienza a darse en el siglo XVII, lo hace en un contexto de reconstitución de la civilización europea (española y católica) sobre la base del mestizaje de las civilizaciones indígena y africana sobrevivientes. En tal sentido, dista de ser un fenómeno meramente formal para pasar a ser entendido como un evento histórico constituyente de una identidad agónica siempre en construcción. 


\section{Alejo Carpentier y el barroco maravilloso}

No hay coincidencia, entre los estudiosos del escritor cubano, respecto de su plena inscripción en el barroco (de hecho, cuando Sarduy construya el "canon" del barroco, lo dejará afuera). Lo cierto es que a una primera etapa afrocubana vinculada a una experimentación novelística de vanguardia a caballo entre surrealismo, cubismo y futurismo (años 40), le sigue el despojo de esos recursos hasta que su producción se convierte en "esa prosa añeja, arcaizante, recargada y barroca que lo distingue desde entonces" (González Echeverría, 2004, p. 151). Pero ha sido el propio autor, en sus ensayos, quien ha sabido valorar el barroco como el estilo propio de América, considerándose parte de él. Dos textos resultan clave a tal efecto: "Problemática de la actual novela latinoamericana" y "La ciudad de las columnas", ambos reunidos en el volumen intitulado Tientos $y$ diferencias, de 1967. En el primero se refiere al barroco como un estilo que nace como desafío de lo considerado de "buen gusto" o perteneciente a la "alta cultura". Un desafío a los criterios de valoración sobre el arte que hace ingresar al objeto kitsch o que se rebela mezclando texturas, amalgamando tradiciones culturales (amerindias, africanas, europeas, neoclásica, moderna) y acercando lo fortuito (como en el surrealismo), como en este párrafo de Problemática...:

Nuestras ciudades tercer estilo: el estilo de las cosas que no tienen estilo. O que comenzaron por no tener estilo, como las rocallas del rococó, los gabinetes de curiosidades del siglo XVIII, las entradas del metro de París, los caballos de tíovivos, los negritos vieneses, barrocos, portadores de mesas o de hachones, los cuadros catastróficos de Monsú Desiderio, la pintura metafísica de Chirico, las arquitecturas de Gaudé o el actual Pop-Art norteamericano. Con el tiempo esos desafíos a los estilos existentes se fueron haciendo estilos. No estilos serenos o clásicos por el alargamiento de un clasicismo anterior, sino por una nueva disposición de elementos, de texturas, de fealdades embellecidas por acercamientos fortuitos, de encrespamientos y metáforas, de alusiones de cosas a 'otras cosas', que son, en suma, la fuente de todos los barroquismos conocidos" (1976, pp. 16-17). 
Esa rebelión - que en su entrevero de objetos semeja al Carnaval, figura muy evocada por la novelística carpentina - sólo se transforma en revelación cuando el escritor le pone palabras. De ahí la tarea: trasponer en palabras el cuerpo del objeto: "Muéstreme el objeto; haga que con sus palabras, yo pueda palparlo, valorarlo, sopesarlo" (Carpentier, 1976, p. 35). La palabra debe poder alcanzar la intimidad de un real cuya existencia es anterior a cualquier vocablo que lo designe, aunque ese real solo adquiera densidad, o plena entidad, a partir de él. Se opera así un trastrueque entre la entidad de un real no tocado por el lenguaje y el lenguaje que materializa en su idealidad a los entes del mundo. Por eso el único estilo capaz de dar cuenta de la corporalidad americana es el barroco: "El objeto vive, se contempla, se deja sopesar. La prosa que le da vida y consistencia, peso y medida, es una prosa barroca, forzosamente barroca, como toda prosa que ciñe el detalle, lo menudea, lo colorea, lo destaca, para darte relieve y definirlo" (1976, p. 35). Sin embargo, lo que esa prosa barroca consigue al rodear a su objeto es despegarse de él; la palabra pierde carácter referencial y el texto se hace contexto. Los diversos niveles contextuales que, tomando en cuenta la teoría de los contextos en boga, desarrolla en Problemática... serán, finalmente textos. $\mathrm{O}$ mejor: un espacio abierto por una negación: la negación de todos los estilos, el estilo de lo que no tiene estilo.

El concepto de barroco deja así atrás el de "real maravilloso" (con el que guarda no pocas similitudes) evocado en el prólogo de la novela El reino de este mundo, de 1949 (texto que luego formará parte de Tientos y diferencias bajo el título "De lo real maravilloso americano"). Lo real maravilloso - cuya gestación, de acuerdo con el testimonio del propio autor, se produce con ocasión de la vista del palacio Sans-Souci, en Haití, "tierra de sortilegios" - es resultado del cruce espontáneo del pasado con el presente, de lo europeo y lo americano. En cambio, en ámbito europeo, con quien lo compara, lo maravilloso es el encuentro forzado de lo foráneo por trucos de prestidigitación, lo que redunda en clisé: "Después de sentir el nada mentido sortilegio de las tierras de Haití, de haber hallado advertencias mágicas en los caminos rojos de la Meseta Central, de haber oído los tambores del Petro y del Rada, me vi llevado a acercar la maravillosa realidad recién vivida a la agotante pretensión de suscitar lo maravilloso que caracterizó ciertas literaturas europeas de estos últimos treinta años" (1976, pp. 94-5). Reunión perenne y fugaz de elementos, esa realidad maravillosa sólo es accesible a una mente ingeniosa, capaz de hallar correspondencias. Las perspectivas fenomenológica (relativa a una percepción sensible y devota) y ontológica (el real milagroso de carácter trascendente) se encabalgan sin que una prevalezca sobre la otra. De este modo, lo maravilloso auténtico sobreviene 
con "una inesperada alteración de la realidad (el milagro), de una revelación privilegiada de la realidad, de una iluminación inhabitual...". La referencia, en ese mismo ensayo, a la figura de Bernal Díaz del Castillo (autor de Historia verdadera de la conquista de la Nueva España, de 1568, editada en 1632), resulta capital y deja entrever rasgos que serán característicos de la literatura americana, pues en la descripción de las proezas de Amadís, confluyen realidad y ficción, hazañas leídas y vividas, mezcla de lecturas de libros de caballería y otros de literatura "seria". El escritor cubano se reconoce así en el absurdo, un estilo que tiende a afianzarse en América. Urdimbre material que abarca los registros verbales y no verbales de una cultura (teatro, literatura, escultura, etc.), el texto barroco se entreteje así con una cierta disposición del alma, con una mística, con una "temible carta de una fe". Ese anclaje es, sin lugar a dudas, el elemento mestizo ("Decir Latinidad era decir mestizaje, y todos éramos mestizos en América Latina; todos teníamos de negro o de indio, de fenicio o de moro, de gaditano o de celtíbero...", dirá en su novela El recurso de método), el cual impide la fatiga y la repetición mecánica de las formas para redundar en una "revelación privilegiada de la realidad". "Barroco" y "real maravilloso" guardan así afinidades que las novelas del autor cubano desarrollarán, a nuestro criterio, con mayor eficacia y amplitud que sus ensayos.

\section{Octavio Paz y el barroco excremental}

Si bien no se limita a ella, la reflexión de Paz sobre el barroco apunta a una de las máximas figuras de la literatura de su país: Sor Juana Inés de la Cruz. El escritor mexicano se ocupa largamente del marco social, político y espiritual que rodea la producción de la poeta en Sor Juana Inés de la Cruz o Las trampas de la Fe (1982). Allí comprende el barroco en su relación con la modernidad $\mathrm{y}$, más específicamente, en su contraste y continuidad con el manierismo y el romanticismo:

Aunque barroquismo y romanticismo son dos manierismos, la semejanza entre ellos recubre diferencias muy profundas. Los dos reclaman, frente al clasicismo, una estética de lo irregular y único; los dos se presentan como una trasgresión de las normas. Pero en la transgresión romántica el eje de la acción es el sujeto, mientras 
que la transgresión barroca se ejerce sobre el objeto. El romanticismo pone en libertad al sujeto; el barroco es el arte de la metamorfosis del objeto. (1982, p. 79)

Si bien Paz comprende estas corrientes artísticas y poéticas en su conexión con la historia sin incurrir en la tentación de los determinismos y causalidades, no duda a veces en afirmar, categóricamente, que "Barroco y vanguardia son dos formalismos" (1982, p. 79). Pero el análisis es rico en contrastes y fecundo en asociaciones, más allá de algunas inconsistencias: "La seducción por la muerte no explica enteramente el fenómeno; hay que agregar la noción de holocausto: la fiesta barroca exige el sacrificio, la destrucción. Estética de lujo, arte de la disipación. El barroco inventó formas pletóricas y henchidas que, en pleno frenesí vital, desfallecen atraídas por el vacío" (1982, p. 202).

En Conjunciones y disyunciones (1969) trata del barroco en su conexión con la corporalidad. La relación entre "cuerpo" y "no cuerpo" resulta clave, "siempre y cuando se entienda que no poseen significación alguna, excepto la de expresar una relación contradictoria" (p. 44). Esa contradicción, que aquí aparece como puramente formal o relacional, se hace carne en el "estilo jesuítico". Fúnebre y vital, estética de lujo y arte de la disipación, el barroco contiene la experiencia del cuerpo caído, que no sublima el excremento. De ahí que el ensayo recorra el proceso de la encarnación y la desencarnación, de la glorificación del cuerpo "en el acto mismo de morir", y refiera la dispersión de aquello (el oro) que se extrae de las entrañas de la tierra: "La transmutación del sol primordial - oro que era de todos, todo que era de oro - en el ojo omnisciente del Estado burocrático-policíaco es tan impresionante como la transformación del excremento en billetes de banco. [...] Un estilo al que podría denominar "barroco excremental”. La Contrarreforma, el "estilo jesuítico" y la poesía hispánica del siglo XVII son el reverso de la austeridad protestante, de la condenación y sublimación del excremento. España extrae el oro de la Indias, primero de los "altares del demonio" (los templos precolombinos) y después de las entrañas de la tierra. En ambos casos, se trata de un producto del mundo inferior, dominio de los bárbaros, los cíclopes y el cuerpo. América es así una suerte de letrina fabulosa abocada ya no más a la retención del oro sino a su dispersión (1978, p. 32). El barroco excremental adquiere así "el rango del estilo mestizo en el que el mestizo no es puramente lo dado como trauma de la invención América sino el elemento central" (Naranjo, 2006, p. 94). 


\section{El neobarroco ${ }^{4}$}

A diferencia del barroco, el neobarroco latinoamericano nace a la vez como reflexión metateórica (Sarduy) y como práctica poética. Ubicándose en los márgenes, los poetas neobarrocos se entregan al goce de la escritura al tiempo que desafían los límites establecidos, en coincidencia con las luchas que por la época tienen lugar en favor de los derechos de las minorías. Es en esa articulación entre políticas de izquierda, prácticas poéticas y actividades libertarias de los grupos minoritarios segregados donde se produce el efecto más radical e innovador de las estrategias de los movimientos de diversidad sexual y de género.

El ciclo del neobarroco se abre en 1955 con Haroldo de Campos. Años más tarde, en 1972, Sarduy lanza su texto fundamental (sin saber, aparentemente, que estaba retomando a de Campos), Barroco y neobarroco, que hace su aparición por primera vez en un volumen coordinado por César Fernández Moreno, América Latina en su literatura (1972). A partir de allí, el propio término se torna fecundo y proliferante. En una nota al pie al texto de Sarduy, Valentín Díaz anota: "La constante con variaciones da forma a una lista que deja ver la fuerza de la noción: primero fue 'Barroco', que engendró al 'Neobarroco', que engendró al 'Neobarroso' (Perlongher), que engendró al 'Hiperbarroco', que engendró al "Transbarroco"” (2011, p. 53).

\section{Haroldo de Campos: transbarroco, canibalismo y antropofagia}

Refiriéndose a un texto que le fuera encomendado por el Museo Guggenheim para el catálogo de la exposición "Brazil: Body and Soul", el poeta y traductor brasilero Haroldo de Campos (São Paulo, 1929-2003) —fundador, con Augusto de Campos y Décio Pignatari, del movimiento nacional e internacional de Poesía Concreta (1956) - nos dice:

Entre otras consideraciones, procuré mostrar la 'pervivencia' (Fortleben, W. Benjamin) transmigratoria de ese estilo en el Brasil, fuera del estricto marco histórico del Seiscientos/Setecientos (Gregório de Matos, Botelho de Oliveira, Padre Vieira, y en el plano de las artes plásticas, Aleijadinho, el escultor-arquitecto de Ouro Preto/Villa

4 Para profundizar en los vínculos entre imagen, cuerpo, estética y política en el neobarroco, remito al artículo "El peregrino inmóvil", de Adrián Cangi, en este dossier. 
Rica, que hace pendant con el indio José Kondori, arquitecto de las iglesias de Potosí, en el Perú, y encuentra una réplica actual en el barroquismo de Oscar Niemeyer).

Dos líneas, dos vetas recorren el barroco histórico: el 'serio-estético' (lírico, encomiástico, religioso) y el 'jocoso-satírico' (aliado, en la prosa, a lo "picaresco", género que se dio, entre nosotros, con variantes y características propias, el "romance malandro", estudiado por Antonio Candido. (De Campos, 2002).

Estas breves líneas resumen el intento de pensar al barroco fuera del siglo XVII — de ahí su capacidad transmigratoria temporal — a la vez que se lo vincula con la corriente satírica y picaresca. En este mismo artículo el autor cita como antecedente del pensamiento barroco latinoamericano un artículo de su autoría "A obra de arte aberta", de 1955, que precede, en más de seis años, a Opera Aperta (1962) de Umberto Eco, y en el que anuncia su programa de un "barroco moderno" o "neobarroco". A partir de allí, los ensayos teóricos de H. de Campos examinan el vínculo entre concretismo, barroco y antropofagia. De lo que se trata es de deconstruir el logocentrismo occidental. Insolente y salvaje, el acto de devorar asegura, por la deglución de ese otro que conquista y sojuzga, lo que Oswald de Andrade en su A marcha das utopías había erigido contra la verticalidad jerárquica del cuerpo, la estética y la catequesis — de ahí su propuesta del montaje, la superposición sarcástica y burlesca que hace estallar los ordenamientos cronológicos y las narraciones lógicas. Como anti-tradición, la antropofagia opera a través de búsquedas marginales y alternativas a la cultura oficial. $\mathrm{La}$ perspectiva "sumisa y reconciliada" del "buen salvaje" se invierte: ahora es el "mal salvaje" el que se convierte en un devorador de hombres blancos. Por eso el barroco se plantea como una estética de la alteridad: "Desde el Barroco, o sea, desde siempre, no podemos pensarnos como una identidad cerrada y concluida, y, sí, como diferencia (en la acepción de J. Derrida), como apertura, como movimiento dialógico de la diferencia, contra el telón de fondo de lo universal. Nuestra entrada en el palco literario es, desde el principio, un salto vertiginoso a la escena del Barroco, o sea, una articulación diferencial con un código universal altamente sofisticado". La incorporación de africanismos e indigenismos, el recurso a la parodia y a la sátira en un juego intertextual carnavalizado, dan cuenta de un proceso de hibridación continua. De ahí que, “[u]na vez dominadas las reglas del juego, explota en un sentido personal, e incluso subversivo, las posibilidades combinatorias del código común: un código siempre móvil y cambiante, en sus reconfiguraciones individuales" (de Campos, 1987). 


\section{Severo Sarduy: la mirada posestructuralista}

Ensayista y novelista, a horcajadas entre la Habana y Paris - espacios que posibilitan encuentros decisivos para su producción, como los que tiene con F. Wahl, Roland Barthes y Lezama Lima - los escritos específicos de Sarduy sobre barroco y neobarroco, como Escrito sobre un cuerpo (1969), compendio histórico donde ubica a Góngora como su epígono; El barroco y el neobarroco (1972); Barroco (1974) y Ensayos generales sobre el barroco (1987), resultan de referencia imprescindible para la comprensión del neobarroco en clave posestructuralista. De acuerdo con sus propias palabras, se trata, en un sentido restringido, de un "esquema operatorio", un "sistema de desciframiento" y una "operación de decodificación". El término "paradigma" se usa pues en un sentido amplio para abarcar la visión epistemológica y cosmológica de Sarduy, la cual es matriz de aquellos conceptos operatorios. Finalmente, el barroco es también uno de los modos de darse de la modernidad (en línea con Eugenio D’Ors), no la hegemónica y racionalista, sino la intempestiva (Nietzsche) y ornamental. Como esquema operatorio, el desarrollo teórico de Sarduy se remite a una serie de procedimientos y mecanismos formales que permiten "leer" un conjunto de obras de diversa procedencia (literaria, artística arquitectónica, cinematográfica). Por eso el neobarroco se ofrece antes como metodología de lectura que como poética. Inspirados, como ha sido dicho, en el posestructuralismo (Barthes, Kristeva, Lacan ${ }^{5}$, Deleuze), esos dispositivos no serían parte, en sentido estricto, de una hermenéutica sino de una semiótica: no hay significado (último), modelo u origen al que quepa llegar, no hay sentido (último) que se trate de restituir. De este modo, sus dos elementos fundamentales: artificio (y sus mecanismos intrínsecos: sustitución, proliferación, condensación) y parodia (que implica la puesta en ejercicio de la intertextualidad y la intratextualidad), a los que se suman: erotismo, espejo y revolución, se ofrecen como dispositivos de lectura antes que de constitución de productos. La pretensión del barroco de ofrecerse como "paradigma", si bien no alcanza a convertirlo en una poética, lo instituye en una forma de conocimiento coherente; como un modo de concebir las relaciones entre las cosas. El término para aludir a este modo de relación es "retombeé": sistema analógico bipolar por el cual elementos análogos y a la vez distantes, sin comunicación o interferencia, sin causalidad o condicionamiento, pueden funcionar como dobles uno de otro. Este privilegio de las estructuras relacionantes lo lleva a su hipótesis más audaz: analizando la ciencia y el arte, Sarduy advierte que la forma subyacente a la teoría de Kepler sobre la elipse es

5 En relación con una hermenéutica de las imágenes, y para un análisis en profundidad acerca de la noción de mirada en Lacan, véase $\square$ Las imágenes barrocas de Lacan $\square$, de Luciano Lutereau en este dossier. 
análoga a la que articula los poemas de Góngora, los cuadros de Caravaggio o la arquitectura de Borromini. Llega así a la conclusión (que retomará más tarde Omar Calabrese) de que esta recurrencia entraña una categoría de la forma que, en el caso de Sarduy, implica además los conceptos de juego, pérdida y placer.

\section{Néstor Perlongher y el "neobarroso" rioplatense}

En Argentina, comienza a hablarse de un barroco moderno o de neobarroco allá por los años 80 (Porrúa, 2007). Será Néstor Perlongher quien propondrá su particular versión del mismo: "En su expresión rioplatense, la poética neobarroca enfrenta una tradición literaria hostil, anclada en la pretensión de un realismo de profundidad que suele acabar chapoteando en las aguas lodosas del río. De ahí el apelativo de neobarroso para denominar esta nueva emergencia" (2008, p. 101). Efecto de superficie, el neobarroco local, a diferencia del barroco áureo, no exige para Perlongher ningún esfuerzo de traducción ni de "restauración" del texto "normal". El término "neobarroso", de su creación, además de ubicar al neobarroco geográficamente en estas cuencas, sugiere una cadena que va del "algo huele mal" al significante hediondo, y que proliferará en secuencias espiraladas: pringoso, baboso. El lenguaje se carga de significantes que sirven para diseminar lo bajo y abyecto, lo que se tapa u oculta, alojando a las minorías y a lo políticamente incorrecto, aquello de lo que no se habla: “...barroco es el "kitsch", el "camp" y el "gay" (2008, p. 116). En verdad, cualquier estilo se presta a ser barroquizado para Perlongher siempre que dé lugar a la parodia, a la carnavalización y a la derrisión; incluso el realismo social rioplatense puede devenir en un barroco gauchesco (como en L. Lamborghini).

Perlongher es, fundamentalmente, un poeta; sin embargo, sus ensayos sobre el neobarroco no eluden el esfuerzo de la conceptualización, enmarcándose en la noción de pliegue de Deleuze y Guatari. De ahí los tres rasgos que describen la escritura y el arte neobarrocos: desterritorialización, pues no se afinca en un lugar determinado sino que se desplaza, llevando así una existencia nomádica en áreas marginales (Italia, España y América Latina); desrealización, en la medida en que es, fundamentalmente, artificio, es decir, negación de un sustrato ontológico como fundamento de lo real, y designificación, pues así como no hay un real que opere de sustrato, tampoco hay un significado último al cual amarrar la cadena de los significantes y la exuberancia metonímica. En última instancia, estos tres rasgos descansan en el abismo entre palabra y ser, lo cual desemboza en ese "lenguaje demente", lúdico y excesivo que caracteriza lo barroco. 


\section{Roberto Echavarren y el barroco "transplantino"}

Si bien la producción teórica de Echavarren en torno del barroco se aloja mayormente en prólogos o prefacios (Perlongher, 2012; A.A.V.V., 2010; de Campos, 2010;), ni el locus ni el género menguan la importancia de la reflexión ni la tornan casual: barroco y neobarroco se hallan para Echavarren en la singularidad de poemas ${ }^{6}$, es allí donde hay que buscarlos, vivenciarlos. La reflexión debe necesariamente atravesar sus texturas, las propuestas de sus diversas sonoridades y climas, de sus diversos estratos de sentido. La enumeración de cada uno de esos recursos es rica en matices, pues abarca una poética que no se deja domeñar por ninguna clasificación definitiva, que propone diferentes estilos. De ahí que el barroco, para el autor, no tenga modelo preconcebido.

Echavarren vincula el neobarroco con la estética de lo sublime haciendo hincapié en la noción de frontera y en la ruptura de la alianza natural entre cosa y palabra. La impronta kantiana en la conceptualización del barroco resulta clave: arte de lo sublime, la postulación de un límite resulta indispensable, pues es en su trasgresión o corrimiento que se gesta el devenir barroco; pasada la línea divisoria, acontece lo espontáneo y la confusión, lo sublime y lo monstruoso: "El arte barroco repudia las formas que sugieren lo inerte o lo permanente, colmo del engaño. Enfatiza el movimiento y el perpetuo juego de las diferencias, dinámica de fuerzas figurada en fenómenos. Es un arte de la abundancia del ánimo y de las emociones, que no son jamás, sin embargo transparentes" (AAVV, 2010, p. 11).

El barroco no se dirime en el ámbito del ser sino de la escritura, por eso prefiere la retórica a la verdad. La conceptualización de esta "idiosincrasia" (de ahí que sea un estilo de vida antes que estilo artístico o poético), es inseparable por ello de la reescritura de poemas de los que su propia escritura se alimenta: los de Sor Juana Inés, Góngora, Severo Sarduy, entre otros. Comprueba en ellos —nos dice en el prólogo a Medusario — - "una dispersión de escrituras. Nada

6 Remitimos, en este mismo dossier, a un texto del propio Echavarren intitulado "La luz de la fantasía", en el que el autor realiza una lectura del poema filosófico de la escritora colonial mexicana Juana Inés de la Cruz, El sueño.

7 La selección de poetas neobarrocos está integrada por los argentinos Arturo Carrera (1948), Reynaldo Jiménez (1959), Tamara Kamenszain (1947), Osvaldo Lamborghini (1940-1985) y Néstor Perlongher (1949-1992); los brasileños Wilson Bueno (1949-2010), Haroldo Eurico Browne de Campos (1929-2003) y Paulo Filho Leminski (1944-1989); el cubano José Kozer (1940); los chilenos Gonzalo Muñoz (1956) y Raúl Zurita Canessa (1950); los mexicanos José Carlos Becerra (1936-1970), Coral Bracho (1951), Gerardo Deniz (de origen español, 19342014) y David Huerta (1949); los peruanos Rodolfo Hinostroza Clausen (1941) y Miroslav Lauer Holoubek (conocido como Mirko Lauer, de origen checo, 1947), los uruguayos Marosa di Giorgio Medici (1932-2004), Eduardo Espina (1954), Eduardo Félix Milán (1952) y Roberto Echavarren (1944) y el venezolano Marco Antonio Ettedgui (1958-1981). En Medusario. Muestra de poesía latinoamericana, Mansalva, Buenos Aires, 2010. 
parecido a una escuela, a la manera de Breton y los surrealistas. [...] Nadie se vuelve prisionero de un procedimiento". Esta dispersión de escrituras es propia del barroco, al que se esfuerza de separar de las vanguardias y del romanticismo, pues “a diferencia del 'compromiso' de la vieja escuela - coloquialismo y propagandismo de tipo populista - no acepta un nivel medio de comunicación poética. No tiene miedo de volverse oscura o demasiado complicada". Se aparta así tanto del subjetivismo ilusorio como del utopismo autoritario. El intento por hacer convivir diversos niveles de sentido (retoma para ello el término acuñado por Rastier: "isotopías"), la lucha de los "particulares" y su pretensión libidinal errática, decanta, en el poema barroco, en largas y complicadas oraciones llenas de paréntesis, cláusulas subordinadas y digresiones interminables, en las que las frases serpenteantes, los ritmos incantatorios "llegan a tal nivel de complejidad que el lector duda por momentos y le cuesta decidir acerca de la corrección de la sintaxis". En tal sentido, el barroco y su hermenéutica no son en Echavarren instancias trascendentales ni metarreflexivas. Es una práctica poética y política que se descubre en la singularidad de ensayos y poemas, en los que palpita una reflexión inseparable de un ritmo y una tonalidad, un movimiento acorde con una vida que experimenta y desafía los límites consagrados. Por eso el barroco es "transplantino": describe una trayectoria transnacional y una peregrinación que es a la vez poética, climática, histórica y lingüística.

\section{Análisis críticos-académicos y ensayísticos}

El poeta, ensayista y especialista Affonso Avila (1928-2012) es considerado en Brasil uno de los mayores referentes sobre el tema. A su primer estudio sobre el barroco en Brasil, especialmente en Minas Gerais, Resíduos Sescentistas em Minas (1967), le siguieron O lúdico e as projeções do mundo barroco I (1971), así como otros ensayos destinados al tema. De evidente tinte idealista, aunque sin limitarse a ese enfoque, el barroco para Ávila no es tan sólo un estilo artístico sino un fenómeno de mayor complejidad y de envergadura global: un estado del espíritu, un estilo de vida, que encuentran en el arte su expresión sublimadora. Lejos de limitarse a la arquitectura y a las artes plásticas, comprende también la poesía; destaca así las obras paradigmáticas de poetas en lengua portuguesa como Gregório de Mattos, Anastácio Ayres de Penhafield, Bento Texeira Pinto, más tarde la de Oswald de Andrade). De las fuentes en las que abreva su estudio - Wölfflin, Weisbach, Huizinga, Schiller y Hatzfeld— Ávila selecciona tres elementos que, a su criterio, son decisivos para la comprensión del barroco: el 
impulso lúdico, la intensión persuasoria y el primado de lo visual. El componente lúdico, centrado en la noción de juego, sirve al autor para el análisis del carnaval y de la fiesta, entendidas como estrategias lúdico-evasivas o como dispositivos de libertad y transgresión contra la tutela reaccionaria del absolutismo y la contrarreforma. El componente visual, a su vez, fundado en una sensibilidad óptica especial, no se limita a la mirada sino que impregna otros repertorios (como la poesía), entroncándose con toda una tradición rica en ensambles y artefactos híbridos, para los que el concretismo proporciona el mayor número de ejemplos. El grafismo visual de textos e inscripciones se deja ver en el arte caligráfica y en las iluminaciones de libros religiosos, en la literatura frástica de los monumentos, etc. La incorporación de la fiesta y la trasgresión de las fronteras entre los diferentes campos, hacen que el barroco resulte así un "espetáculo total", y también un "espetáculo lutuoso", en la medida en que los tópicos barrocos sobre la muerte y la vida breve sirven paradójicamente para la celebración de la vida.

La compilación realizada recientemente por el Avila, Barroco. Teoría e Análise (2013) reúne en un único volumen una selección de artículos, ensayos y trabajos de investigación aparecidos en la revista Barroco a lo largo de sus 25 años de existencia (desde 1969 hasta 1994). Una variada constelación de autores y textos ofrece aquí un cuadro de situación del barroco en Europa, Brasil y el resto de América, con predominio de los estudios de tipo arquitectónico y plástico, con profusión de ejemplos. Más allá de la heterogeneidad de los puntos de vista y de los ángulos de análisis del tema, una tesis común se deja entrever: la de la especificidad del barroco americano respecto del español, y la imposibilidad, a su vez, de considerar a América como una unidad o un bloque compacto. El aporte inmigratorio sella algunas divergencias entre el barroco mexicano y el de Brasil y de América del Sur. Contra la teoría de la invariancia (destacada especialmente en el artículo de Graziano Gasparini), se resaltan los trazos únicos y diferenciales; contra el esquema tradicional que supone que el estilo barroco "se cria en Europa, passa à América e aqui comença a transformarse, a alterar-se, até que se americaniza", se sostiene que el barroco americano "surge na América, se forja na América" (J. A. Manrique, p. 176), configurando desde el principio un lenguaje formal propio. Lejos de ser una imposición superficial y artificial, el barroco aquí establece su propio proceso. Si el esquema tradicional presupone que América es un continente vacío — vaciedad que se corresponde con la teoría del simple injerto- aquí en cambio se subrayan las tensiones que hacen que los modelos europeos tengan que ajustarse a las maneras, gustos y procesos de estilos de las sociedades americanas, "de tal maneira que há sempre una "triangulaçâo" para esa fonte ideal de cânones" (p. 177). 
Especialmente esclarecedores resultan aquellos trabajos destinados al estudio del barroco portugués, en particular los que versan sobre la pintura decorativa denominada grutesco (o brutesco), cuyas notas manieristas de extravagancia y ambigüedad se combinan con el recurso a lo fantástico, lo burlesco y lo maravilloso. Insertas en un imaginario que tiende a negar la espacialidad, la proliferación de hibridismos forman parte de los revestimientos de las "igrejas forradas a ouro", signando así el triunfo de un barroco fundamentalmente decorativo que deja intactas algunas estructuras básicas (como la planta cruciforme para las iglesias). El barroco americano adopta así características singulares según la región (exuberante en México, parsimoniosa y austera en América del Sur), y sirve para "vestir" cajas arquitectónicas muy simples, contribuyendo así a la disociación entre arquitectura y ornamento - anotemos de paso que la metáfora del "vestido" que "reviste" deja de alguna manera intacta la tesis del vacío, o mejor dicho, de la "desnudez", ya sea del habitante originario de estas tierras como del territorio mismo.

Autora de $O$ realismo maravilhoso (2008) y de Barroco e modernidade (1998), Irlemar Chiampi acomete en el primero de esos textos la tarea de distinguir conceptualmente las nociones de "realismo mágico", "real maravilloso", "literatura fantástica" y "barroco" a partir de las discusiones que a fines de los 40 inicia la crítica literaria a propósito del fenómeno de renovación ficcional de la literatura latinoamericana contra la tradicional literatura realista. Pese al innegable aporte de esos estudios — que tienen el mérito de empezar a cubrir las deficiencias y la falta de análisis crítico en la región - la "unilateralidad" en los enfoques adoptados le permite a la autora pensar con mayor rigurosidad las narrativas en consideración. En efecto, a la oscilación entre el enfoque fenomenológico (lo mágico como disposición del autor, cuya figura resulta sustancializada) y el enfoque ontológico (ya sea que naturalice lo irreal, o se sobrenaturalice lo real: lo maravilloso como inmanencia), se agrega la confusión entre los géneros fantástico y simbólico, amén de la habitual adherencia de los análisis a la superficie temática y al examen de los caracteres de los personajes (como si fueran la voz del autor). Abdicando de la expresión "realismo mágico" por combinar términos que pertenecen a dos series diferentes, la autora se aboca a la diferenciación entre literatura fantástica y real maravilloso, diferencia que aparece explicitada en este párrafo de notable economía: "Ao contrário 
da "poética da incerteza" [característica de la literatura fantástica], calculada para obter o estranhamento do leitor, o realismo maravilhoso desaloja qualquer efeito emotivo de calafrio, medo ou terror sobre o evento insólito. No seu lugar, coloca o encantamento commo un efeito discursivo pertinente à la interpretação não-antitética dos componentes diegéticos. $\mathrm{O}$ insólito, em óptica racional, deiza de ser o 'outro lado', o desconhecido, para incorporar-se ao real: a maravilha é(está) (n)a relidade” (2008, p. 59).

A diferencia de lo maravilloso "puro", en el real maravilloso la causalidad (continuidad causa-efecto) es restablecida, pero a diferencia de lo fantástico, ella no es conflictiva, sino difusa. La discontinuidad entre causa-efecto (por suspensión de coordenadas espacio-temporales) se refuerza con la contigüidad entre real e irreal. Pero la lógica que combina los imposibles no los antagoniza. Asturias, Carpentier, Arguedas, Roa Bastos, Vargas Llosa, Onetti, García Márquez consiguen, en sus textos, que la "lucha primordial" entre los contrarios - que en el género fantástico originan lo insólito, incómodo a la razón, quien debe expedirse - se disuelva en favor de una convergencia armoniosa y despreocupada en el realismo maravilloso. Lo más importante del análisis se centra en las estrategias narrativas (puntos de vista narrativos, etc.) que posibilitan ambos efectos: de extrañeza inquietante en el primero, de encantamiento en el segundo. En este contexto, lo que aporta el barroquismo son recursos y estrategias narrativas al realismo maravilloso: cambios de perspectiva y puesta en abismo. La multiplicación (o distorsión) de los significantes apuntan a un objeto indescriptible al que, no obstante, se pone el empeño en nombrar.

$$
* * *
$$

La idea directriz del conjunto de artículos que componen el texto La modernidad de lo barroco (1998), de Bolívar Echeverría (1941-2010), es que el barroco forma parte de un ethos histórico inscripto en la modernidad. El pensador ecuatoriano se inscribe así en la línea de aquellos que consideran al barroco en su especificidad histórica, que se plantea como algo más que como un simple estilo artístico. Entendido en su sentido amplio como modo de vida; morada y abrigo; uso, costumbre o comportamiento automático; pero, básicamente, como estrategia y como práctica, este ethos no es homogéneo, sino que comprende en sí los momentos clásico, realista, romántico y barroco, según sea el grado de compromiso de cada cual con la lógica capitalista. El fenómeno es abordado así desde 
las perspectivas hegeliano-marxista, fenomenológica y existencialista. De ahí que el barroco sea visto como una estrategia de resistencia frente al capitalismo realista y puritano; pero su poder de transformación no se cifra en la revolución, la utopía o en un más allá histórico, sino en la imaginación. Una imaginación que teatraliza, se mofa, parodia y visualiza lúcidamente los impedimentos de una vida administrada como la presente: "El ethos barroco no borra, como lo hace el realista, la contradicción propia del mundo de la vida en la modernidad capitalista, y tampoco la niega, como lo hace el romántico; la reconoce como inevitable, a la manera del clásico, pero, a diferencia de éste, se resiste a aceptarla, pretende convertir en 'bueno' el 'lado malo' por el que, según Hegel, avanza la historia” (1998, p. 40). Es, a todas luces, una puesta en escena, una “'des-realización' de la contradicción y la ambivalencia que, sin pretender resolverlas, intenta de todas maneras neutralizarlas, aplicándoles para ello el status de lo alegórico" (1988, p. 176). La propensión barroca a poner en tensión fuerzas contrapuestas se exaspera en América por el encuentro de culturas completamente extrañas entre sí: la ibérica católica y la indígena y negra. El mestizaje producto de este encuentro es analizado por el autor en términos semióticos, lo cual implica poner de relieve los códigos comunicacionales y expresivos de ambas culturas y sus modos de relación, es decir, qué lugar ocupa cada una en el juego de fuerzas configurado. El autor rechaza así los modelos de la biología y de la química: "El mestizaje —nos dice (p. 51) — , el modo de vida natural de las culturas, no parece estar ni en la figura de la química (yuxtaposición de cualidades) ni en la biología (cruce o combinatoria de cualidades), a través de las que se lo suele pensar. Todo indica que se trata más bien de un proceso semiótico al que bien se podría denominar "codigofagia". Tomando aquellos conceptos que hemos desarrollado a propósito de Haroldo de Campos y de Oswald de Andrade, mestizaje no es, pues, para Echeverría, un proceso armónico o pacífico de fusión, sino resultado de un acto de devoramiento que pasa por la destrucción del centro de simbolización constitutivo de lo diverso para apropiarlo e integrarlo. En América, la codigofagia fue llevada a cabo por iniciativa, no de los dominadores, sino de los dominados (mestizos, cholos, criollos e indígenas) e implicó la transformación del código dominante por su asimilación a las ruinas del código dominado, virtualmente destruido: "Las subcodificaciones o configuraciones singulares y concretas del código de lo humano no parecen tener otra manera de coexistir entre sí que no sea el de devorarse las unas a las otras; la de golpear destructivamente en el centro de simbolización constitutivo de lo que tienen enfrente y apropiarse e integrar en sí, sometiéndose a sí mismas a una alteración esencial, los restos aún vivos de lo que quedan de ella después" (1998, pp. 51-52). 
En Ficciones barrocas. Una lectura de Borges, Bioy Casares, Silvina Ocampo, Cortázar, Onetti y Felisberto Hernández (2010), Carlos Gamerro propone la distinción entre "escritura" y "ficción" barroca a fin de definir el estatuto barroco de algunos textos limítrofes. La "escritura" barroca tiene lugar en el nivel de la frase, y se refiere al uso de las palabras para la descripción de algo o alguien. Ya sea que el referente se oculte (Góngora) o se desintegre (Quevedo), lo importante en este nivel es la semiosis potencialmente infinita a que da lugar la proliferación de términos (Carpentier), la cual desemboca, en el neobarroco, en una escritura que se agota en sí misma (Severo Sarduy, Lezama Lima). La "ficción" barroca atañe en cambio, no a la palabra, sino a la estructura, y se refiere al modo en que los planos estructuran la trama; esos planos deben corresponder a órdenes de realidad diferentes entre sí (sueño/vigilia; copia/original; ficción/verdad; teatro/mundo; reflejo/modelo), los cuales se superponen y cruzan de modo de generar una experiencia de incertidumbre o inquietud. De este modo, un autor puede tener una escritura barroca (proliferante, de superficie) y ser realista (hay un solo plano de realidad, como en Carpentier), o tener una escritura austera y ser barroco por el planteo de múltiples planos (Borges). Pero lo que inscribe para Gamerro a un autor en el barroco es el pacto de lectura por el cual la percepción de lo real se torna vacilante por la superposición de mundos y de las coordenadas espacio-temporales: "No es barroca una ficción en la que el personaje sueña, sí lo es si no sabe si sueña o está despierto (como en $\mathrm{La}$ vida es sueño)" (Gamerro, 2010, p. 50). De este modo la ficción barroca puede atravesar diferentes géneros, aunque se aloja con preferencia en el fantástico, dado el explícito cruce entre mundos que tiene lugar en el mismo (de ahí la consideración de que Bioy, Borges y Ocampo son barrocos).

\section{$* * *$}

En cuanto a la producción de estudiosos chilenos sobre el tema, merece destacarse el texto de Barroco y Neobarroco (2011), de Ángela Luz Martínez. Su planteo parte de una aseveración: hay un germen barroco susceptible de ser rastreado en las crónicas del "descubrimiento": los diarios de Cristóbal Colón y de Américo Vespucio; de esta manera, retrotrae el nacimiento del barroco al siglo XV para extenderlo, merced a líneas de continuidad, hasta el mundo contemporáneo. Esos textos originarios se construyen, de acuerdo con la autora, sobre un vacío hipotetizado (primero) y luego sobre una deformidad (la realidad recién 
"descubierta"), y echando mano de un procedimiento escritural que apela tempranamente a los recursos estilísticos propios del barroco: el fingimiento, el truco, la acomodación y el disimulo. Los excesos de lenguaje y la exuberancia en la descripción de lo real deben, pues, entenderse a la luz de un problema que es epistemológico y ontológico a la vez: aquél que signa la investigación científica fundada en hipótesis, y aquél que, sobre esa base, delinea las realidades recién descubiertas. La superposición de estos dos planos decanta pues en los excesos que caracterizan el estilo. La estética aparece así subordinada a la epistemología y la realidad a la escritura: la potencia performativa de la escritura (sobre)determina la realidad. Lo interesante del estudio de Martínez es que pone el foco en un hecho imposible de desconocer para la comprensión del ser americano: el momento de la colisión de los mundos. Sin embargo, a la hipótesis que sostiene el punto de partida del análisis, caben las objeciones señaladas por Chiampi (2008): el esfuerzo por caracterizar una tradición americana ininterrumpida, la lleva a conciliar (quizá, erróneamente) el elemento "mágico" de las crónicas (cuyo componente sobrenatural es resultado tanto del deslumbramiento de los europeos como de la influencia de las leyendas medievales), con el juego de verosímil e inverosímil propio de la literatura barroca maravillosa. El análisis se completa con un estudio sobre Sor Juana Inés de la Cruz y prosigue con Lezama Lima y Severo Sarduy, poéticas que entroncarían sin dificultad con los textos de los primeros cronistas: "En consecuencia lo que debe resaltarse - nos dice en la conclusión - es que existe una coherencia irrefutable entre las primeras poéticas barrocas del sigo XVII indiano y las últimas de la expresión barroca latinoamericana. En tal sentido, subraya, "las poéticas barrocas americanas del siglo XVII al XX son coincidentes porque se han abocado a la reflexión epistemológica y filosófica, y porque se han preocupado sensiblemente por discernir cual es el lugar de Nuestra Historia en la Historia” (2011, p. 295).

\section{Conclusión}

Como se desprende del recorrido que hemos realizado, el barroco en AL se propone a la vez como programa estético y político: arte antioccidental (Perlongher) por su desafío del logos, se convierte en arte de la contraconquista (Lezama Lima), en práctica antropófaga (de Campos), desafiante pero también festiva, sin las reminiscencias melancólicas del barroco continental europeo al que alguna vez hiciera referencia Walter Benjamin. Invocando un pasado del que aún no se ha repuesto, el barroco es la huella de un acto violento, la cicatriz 
de una herida que no ha sido cerrada. Pero en este ejercicio no hay duelo por el objeto perdido o ideal sino celebración y experimentación lúdica y carnavalesca. Estética de lujo y arte de la disipación, la corporalidad no reniega del excremento (O. Paz). Se busca exasperar las tensiones entre el plano de la expresión y el plano del contenido. Los procedimientos estilísticos ponen énfasis en el aspecto fónico del lenguaje como modos de acceder al significado de las cosas, al tiempo que manifiestan su rebelión contra los sistemas centrados y simétricos. La estructura barroca se deja ver desde un ángulo, desde un trayecto o en un instante del tiempo. No hay punto de vista privilegiado pues se apuesta al descentramiento y la ilusión: la imaginación barroca escapa al canon (Bollini, 2013). El uso de múltiples registros del lenguaje (códigos provenientes de la biología, las matemáticas, la cibernética, la astrología, etc.), se combina en literatura con jergas dialectales, neologismos, cultismos. El lleno material y la pulsión vital crean un espacio donde no hay vacíos, donde todo es movimiento, curva y contracurva, pliegue, expresión de una potencia que no cesa. Como observa Carpentier, el exceso de materialidad, la exuberante naturaleza y la deformidad que incitó, ya por entonces, la imaginación de los primeros exploradores y cronistas — quienes escogieron una "perla irregular" ("barrueco" o "berrueco"), una joya falsa, para expresar los profundos cambios que produjo en la percepción la llegada a América - se trastrueca en escritura proliferante y en claroscuros mortecinos. El interior barroco latinoamericano es un útero de bordes irregulares que se cierra sobre su habitante fugaz y por momentos lo asfixia. La escritura barroca persigue este mismo efecto sin pretender ser efectista, tan solo festiva (Avila, 1971). Y si bien pueden abundar las imágenes de la muerte que aludirían por sí solas a la nostalgia de un mundo perdido, ellas se combinan con otras en las que la ironía y la parodia (de Campos) subvierten toda posibilidad de restauración de un tiempo perdido. Todas estas esas tensiones pueden no resolverse, pueden no conciliarse. No hay armonía en la desemejanza manifiesta entre los planos. Incluso en el chispazo puede abrirse paso la violencia. La provocación de los límites da lugar al sublime como monstruo (Hernández Ramírez, 2016), más que como silencio. La figura de un arlequín infame sería su correlato. Como señalan la mayor parte de los estudios específicos, esas tensiones dan cuenta de un barroco que es propio de América, resultado de un mestizaje conflicto, producto del encuentro y desencuentro de culturas extrañas entre sí: la ibérica católica, la indígena y la negra.

Por su parte, el modo de experimentación neobarroca, inspirado en el posestructuralismo, no se da al modo de las vanguardias que, a su manera, tienen un 
proyecto, sino que es una práctica inmanente sin metas preestablecidas (Echavarren). Sin embargo, resulta políticamente subversivo al promover inestabilidades y corroer la fijeza. Provocador y anárquico, marginal y "barroso" (Perlongher) el neobarroco se enlaza a la hermenéutica en la medida en que se ofrece a la recomposición de los desechos y los fetiches de la cultura sin pretensión "restauradora" y sin invocar los derechos del texto "normal". Una hermenéutica, claro está, entendida como práctica de reescritura más que de interpretación, propensa a una existencia cuasi-parasitaria en la que los textos de los otros son a la vez materia nutricia y hospitalaria. Sin limitarlo a un estilo o a un período específico de la historia, el (neo)barroco resulta pues una categoría clave para la construcción de una hermenéutica americana, un concepto "operatorio" (en el sentido que le da Sarduy y también Deleuze), aun cuando reniegue de toda exterioridad, aun cuando se intente preservarlo de la tentación de que resulte "aplicable", traicionando así el fondo oscuro que posibilita su emergencia. El (neo)barroco sería así un concepto que remitiría a un universo habitado por cuerpos cuyas intensidades vuelven imprecisas las fronteras entre las cosas; un concepto eficaz para la construcción de una hermenéutica que no puede dejar de prestar oído a lo disonante. O en la que la disonancia interroga un modo de pensarse a sí mismo que llega hasta el

Recebido em: 12.05.2016 Aprovado em: 30.07.2016

límite de la tierra. Una patria y una territorialidad grande, prolífica y visceral, llamada Nuestra América.Avila, Affonso, O lúdico e as producôes do mundo barroco. Uma linguagem a dos cortes. Uma consciencia a dos luces. Sâo Paolo, Perspectiva, 2012. (org.) Barroco. Teoria e Análise. Sao Paolo, Perspectiva, 2013.

Benjamin, Walter, Origen del Trauerspiel alemán, Buenos Aires, Gorla, 2012.

Bollini, Horacio, El Barroco Jesuitico-Guaraní. Estética y atavismo. Buenos Aires, Las cuarenta, 2013.

Calabrese, Omar, La era neobarroca, Madrid, Cátedra, 1989;
Carpentier, Alejo, Tientos y diferencias, Buenos Aires, Calicanto, 1976

Croce, Benedetto Storia dell'eta barocca in Italia. Pensiero-poesia e literatura. Vita morale. Bari, Laterza, 1957 [ $1^{\circ}$ ed. 1929].

Chiampi, Irlemar, O realismo maravilhoso, Sâo Paulo, Perspectiva, 2008.

pectiva, 1998

Barroco e modernidade, Sâo Paulo, Pers-

De Campos, Haroldo, Galaxias, Buenos Aires, La flauta mágica, 2010.

."Barroco, neobarroco, transbarroco", en Revista Sol Negro, 2002. 
."Tradición, traducción, transculturación, historiografía y ex-centricidad", en Filología, Año XXII, $\mathrm{n}^{\circ}$ 2, Instituto de Filología y Literaturas Hispánicas “Dr. Amado Alonso", Buenos Aires, 1987.

Deleuze, Gilles, El pliegue. Leibniz y el barroco, Buenos Aires, Paidós, 2005.

Echavarren, Roberto; Kozer, José; Sefamí Jacobo, $\mathrm{Me}$ dusario. Muestra de poesía latinoamericana, Buenos Aires, Mansalva, 2010.

Echeverría, Bolívar La modernidad de lo barroco, México DF., Ediciones Era, 1988.

García de La Concha, Víctor "Barroco: categorías, sistema e historia literaria" Actas del II Congreso de la Asociación Internacional Siglo de Oro. Editores: Manuel García Martín, 1990, pp. 59-74.

González Echeverría, Roberto, Alejo Carpentier: el peregrino en su patria, Madrid, Gredos, 2004.

Hauser Arnold, Historia social de la Literatura y el Arte, Barcelona, Labor, 1978.

Hernández-Ramírez, Azucena “Barroco, monstruosidad y mercancía en Historia general y natural de las Indias, de Gonzalo Fernández de Oviedo", en Hispanic Review, Vol. 84, N 1, 2016.

Lezama Lima, José, Ensayos Barrocos, Buenos Aires, Colihue, 2014.

Maravall, José Antonio, La cultura del barroco, Barcelona, Ariel, 2012;

Marzo, José Luis, La memoria administrada, Buenos Aires, Katz, 2010.

Marcos Wasem, Barroso y sublime: poética para Perlongher, Buenos Aires, Ediciones Godot, 2008

Martínez, Luz Angela Barroco y Neobarroco. Del descentramiento del mundo a la carnavalización del enigma. Santiago de Chile, Editorial Universitaria, 2011.
Naranjo, Rodrigo, "Barroco excremental", en Aisthesis N³9, 2006.

Paz, Octavio. Sor Juana Inés de la Cruz o Las trampas de la fe. México, FCE, 1985.

Conjunciones y disyunciones. México, Joaquín Mortiz, 1978.

Perlongher, Néstor, Prosa plebeya, Buenos Aires, Colihue, 2008,

Poemas completos, Buenos Aires, La flauta mágica, 2012.

Picón Salas, Mariano De la conquista a la Independencia, México DF, FCE, 1944.

Porrúa, Ana “Sobre Perlongher y el neobarroco en sus orígenes", Boletín 13-14, Centro de Estudios de Teoría y Crítica Literaria, Universidad Nacional de Mar del Plata, 2007-2008

Sarduy, Severo El barroco y el neobarroco. Buenos Aires: Cuadernos del Plata; 2011

. Ensayos generales sobre el barroco. Buenos Aires: Sudamericana, 1974.

Skrine, Peter, 'Una cultura entre el pesimismo y la exuberancia”, en El barroco, El Correo de la Unesco, № 9, 1987, pp. 4-8.

Snyder, Jon, La estética del Barroco, Madrid, Machado grupo, 2014.

Weisbach, Werner, Barroco, arte de la contrarreforma. Madrid, Espasa-Calpe, 1948

Wölfflin, Heinrich, Conceptos fundamentales de la historia del arte, Madrid, Espasa Calpe, 2007.

Zea, Leopoldo "Nacimiento de una cultura mestiza", en El barroco, El Correo de la Unesco, No 9, 1987, pp. 34-35.

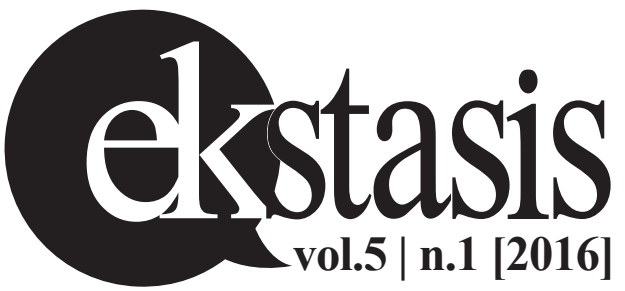

